\title{
Humoral response and evolution of Echinococcus infection in experimentally infected sheep
}

\author{
Resposta humoral e evolução à infecção por Echinococcus em ovinos experimentalmente infectados \\ Roberto Lamberti ${ }^{1}$; Laura Cavagion ${ }^{1}$; Antonio Gatti ${ }^{2}$; Claudio Calvo ${ }^{1}$; Lilia Gino ${ }^{1}$; Veronica Véspoli Puches ${ }^{1}$; \\ Angela Rosa Alvarez'; Emiliano Alvarez ${ }^{1}$; Mariela García Cachau ${ }^{1}$; Mariela Morete ${ }^{1}$; Edmundo Larrieu ${ }^{1,2 *}$ \\ ${ }^{1}$ Facultad de Ciencias Veterinarias, Universidad Nacional de la Pampa, General Pico, Argentina \\ ${ }^{2}$ Facultas de Ciencias Veterinarias, Universidad Nacional de Río Negro, Choele Choel, Argentina
}

Received August 17, 2013

Accepted December 2, 2013

\begin{abstract}
There is little information on the humoral response of sheep experimentally infected with Echinococcus granulosus. Thus, the objective of this study was to evaluate this response and measure its evolution. Doses of 10, 100, 1000 and 10000 E. granulosus eggs were prepared and inoculated via intraruminal puncture. Blood samples were obtained before inoculation and every $48 \mathrm{~h}$ after inoculation, until they became seropositive. Thereafter, they were taken monthly for the first year and then every three months until 1700 days of observation had been completed. An ELISA test, with total hydatid fluid antigen, was used for immunodiagnosis. The average optical density of the 12 inoculated sheep was found to be above the mean cutoff value 10 days after inoculation, went on increasing until 180 days after inoculation and remained above the cutoff level until the end of the observation period. This confirms that the antibody response of sheep to E. granulosus infection occurs before production of hydatid fluid and that activation, mobilization and establishment of oncospheres in the tissues generates a persistent response from the host's immune system.
\end{abstract}

Keywords: Echinococcosis, humoral response, sheep.

\section{Resumo}

Existe pouca informação sobre a resposta imune humoral de ovinos experimentalmente infectados por Echinococcus granulosus. O objetivo deste estudo é avaliar a resposta imune por anticorpos em ovinos infectados. Os ovinos receberam doses de 10,100, 1.000 e 10.000 ovos de E. granulosus por via intrarruminal. Amostras de sangue foram colhidas antes e após infecção, a cada 48 horas, até a detecção de anticorpos anti-E. granulosus e após, colheram-se amostras mensal e trimestralmente, no primeiro ano até 1.700 dias de infecção. No imunodiagnóstico, utilizou-se o ensaio imunoenzimático indireto (ELISA-teste) e como antígeno total, líquido hidático. Na deteç̧ão de anticorpos anti-E. granulosus no soro das 12 ovelhas, a densidade ótica esteve acima do ponto de corte, após 10 dias de infecção, aumentando até 180 dias pós-infecção, e permanecendo acima desses dias até o final do experimento. Isso confirma que a resposta por anticorpos em ovinos infectados por E. granulosus antecede a produçáo de líquido hidático, e que a ativaçáo, mobilidade e permanência das oncosferas nos tecidos possibilita a resposta imune dos hospedeiros.

Palavras-chave: Equinococose, resposta imunológica, ovinos.

\section{Introduction}

Cystic echinococcosis (CE) or hydatidosis is a parasite zoonosis produced by a cestode of the Taeniidae family, Echinococcus granulosus, which was first described in 1786. It needs two mammalian hosts to complete its life cycle: one definitive host (a carnivore, especially dogs), where it develops the adult or strobilar phase, and an intermediate host, where it develops the larval or metacestode phase (THOMPSON; McMANUS, 2001).

\footnotetext{
${ }^{*}$ Corresponding author: Edmundo Larrieu

Facultad de Ciencias Veterinarias, Calle 5 y 116, CP 6360, General Pico,

La Pampa, Argentina

e-mail: ejlarrieu@hotmail.com
}

When E. granulosus eggs are eliminated by a dog or some other carnivore, and are ingested by a susceptible host (especially sheep), they reach the stomach and there undergo disruption of the embryosphere and activation of the oncosphere. They penetrate the intestinal microvilli and pass into the lymphatic and venous systems, to lodge definitely in a visceral organ, preferably the liver or lungs.

The larva or metacestode that develops is typically unilocular, polymorphic and full of fluid. It has a complex structure consisting of an internal germinal membrane composed of cells with a circular or oval nucleus, and an external cuticular, acellular elastic membrane 
surrounded by a fibrous adventitious membrane produced by the host (ECKERT et al., 2001)

It is one of the main zoonotic diseases, with the highest prevalence among such diseases in Argentina, Uruguay, Chile, Peru and southern Brazil. It produces high regional costs in farm animal production relating to the value of confiscated viscera and loss of wool, milk and meat production; and for the health system, relating to the costs of hospitalization and treatment of infected people (LARRIEU; ZANINI, 2012).

The humoral response to E. granulosus infection in sheep has been poorly studied. Antigen 5 antibodies were detected in experimentally infected sheep from 120 days after infection onwards (CONDER et al., 1980). A humoral response was detected 20 days after infection of adult sheep, by means of ELISA (LARRIEU et al., 2009).

There is little information on the continuity of this humoral response. Therefore, the objective of this study was to evaluate the humoral response and its evolution over time in sheep experimentally infected with different doses of E. granulosus eggs.

\section{Materials and Methods}

Experimental lambs were randomly selected from a flock in General Pico, Province of La Pampa, and were numerically identified using ear-tags. Four groups of three animals each and one group with three animals (control) were established.

Adult tapeworms of the species E. granulosus were obtained from 54 dogs using arecoline hydrobromide and were kept in normal saline solution with penicillin at $8-10{ }^{\circ} \mathrm{C}$.

Inoculums of $5 \mathrm{ml}$ of saline solution with doses of 10, 100, 1000 and 10000 Echinococcus granulosus eggs, isolated from the mature proglottids in inverse microscopy, were prepared and individually applied using intraruminal puncture in each group of three animals. The control group received $5 \mathrm{ml}$ of saline solution.
Blood $(10 \mathrm{ml})$ was obtained by means of venipuncture of the jugular vein, from animals in the standing position with their heads held to one side, using disposable syringes and 25/8 gauge needles. The first blood sample was taken prior to inoculation, and post-inoculation samples were taken every $48 \mathrm{~h}$ until the animals became seropositive. Samples were then taken monthly for the first year and subsequently every three months until 1700 days of follow-up had been completed.

An enzyme immunoassay (ELISA) was carried out for immunodiagnosis, using the antigen from total hydatid fluid (EIE.LHT), in accordance with a previously described technique (GATTI et al., 2007; LARRIEU et al., 2009).

During the study, the animals were maintained on a cattle farm, without dogs. There were no deaths and/or serious diseases among the animals.

Calculations for regression analysis, one-way ANOVA and the Tukey and Fisher tests were carried out using the Minitab 15 software.

\section{Results}

All the animals were seronegative before experimental inoculation.

Two animals (16.7\%) inoculated with 10 and 1000 eggs, showed a humoral response seven days after infection. At 30 days, four more sheep (33.4\%) were detected, at 90 days, eight sheep (66.8\%), and at 150 days, 10 sheep $(83.3 \%)$. The two sheep that did not initially react showed a humoral response at 540 days (inoculated with 100 E. granulosus eggs) and at 1200 days (inoculated with 10000 E. granulosus eggs) (Figure 1).

The mean optical density of the 12 inoculated sheep exceeded the average cutoff value by the tenth day after inoculation, went on increasing until 180 days after inoculation and then remained above the cutoff level until the end of the observation period (Figure 2). All the sheep maintained the humoral response from

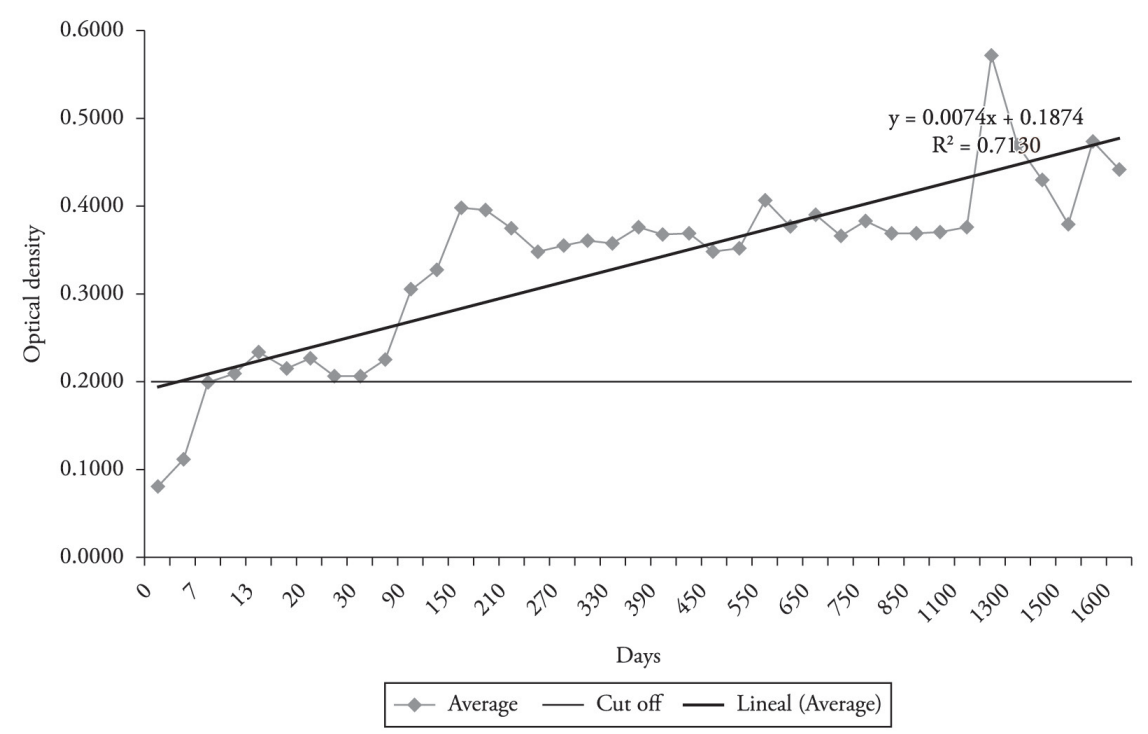

Figure 1. Longitudinal follow-up of the response to infection among sheep experimentally inoculated with different doses of Echinococcus granulosus eggs. 


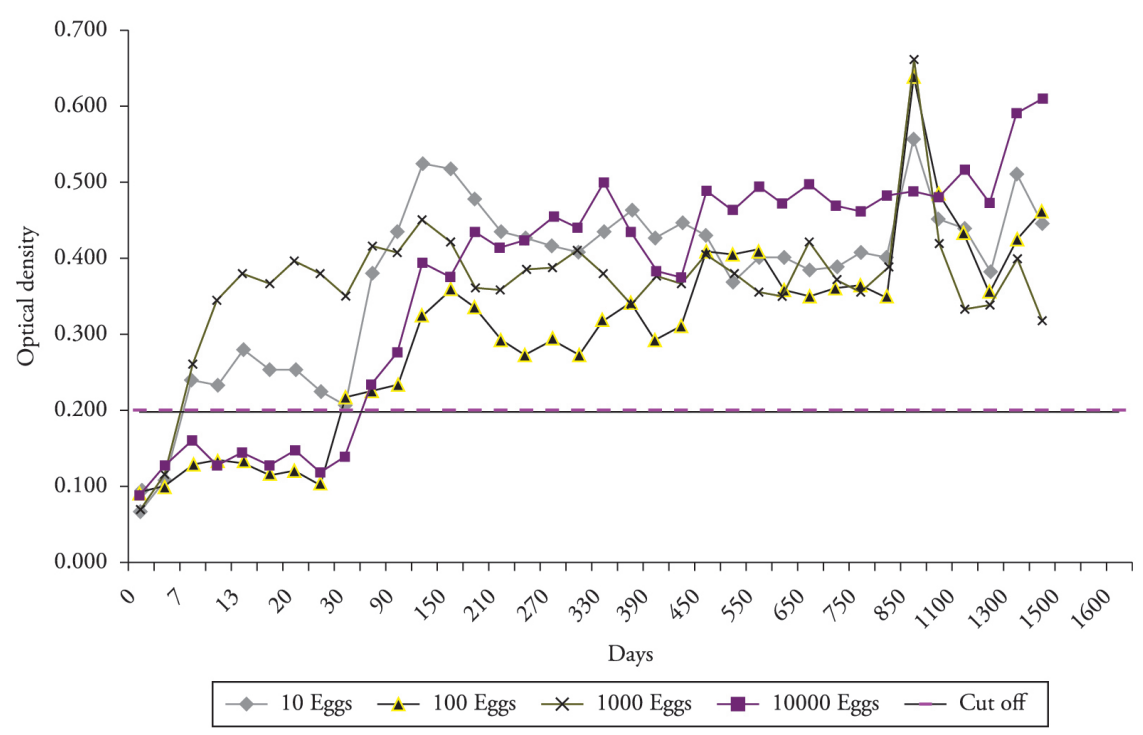

Figure 2. Longitudinal follow-up of the response to infection among sheep experimentally inoculated with Echinococcus granulosus.

the time when it was first manifested until 1700 days had been reached. The regression line for the mean optical density showed a tendency to rise both at the beginning of the observations and during the period after 180 days, although the coefficient $\left(\mathrm{R}^{2}\right)$ presented a high association $(71 \%)$. A significantly high measurement was observed at 1400 days.

Significant differences in humoral response were observed with regard to the number of inoculated eggs, considering the whole observation period $(\mathrm{F}=3.01, \mathrm{p}=0.032)$. From analyzing $95 \%$ confidence intervals for the average individual, 95\% confidence intervals simultaneously (Tukey) and 95\% confidence intervals (Fisher test), differences were only observed between doses of 100 eggs and the remaining doses.

\section{Discussion}

The present study followed the humoral response in sheep experimentally infected with Echinococcus granulosus eggs over a period of 1700 days, detecting the humoral response from the time of entry of the infecting oncospheres, which occurred seven days after infection in $16.7 \%$ of the sheep, reached $100 \%$ at 1200 days and was then maintained over time.

Previous observations on 500-day post-inoculation followups showed similar behavior (LARRIEU et al., 2009), thus demonstrating, when associated with histological studies, that the cysts became fertile with the presence of protoscolices 300-360 days after inoculation and that live oncospheres can be identified in viscera 300 days after inoculation and in the presence of formed hydatid cysts.

In the same study, a humoral response was detected 10 days after infection and was maintained over the whole period of observation. Initially, the humoral response was proportional to the quantity of inoculated eggs, but the differences diminished with time (LARRIEU et al., 2009). This observation was confirmed in the present study, i.e. there was little relationship between the dose and response.

Thus, this confirms that in sheep the antibody response to E. granulosus infection occurs before production of hydatid fluid and shows that activation, mobilization and establishment of oncospheres in tissues generates a persistent response from the host's immune system.

Many serological reactions, in sheep or in humans, may be classified as false positives because of the impossibility of finding a hydatid cyst in the host. However, these reactions could be due to E. granulosus infection in the oncosphere stage or in the early phase of the metacestode development process.

Various sources of antigen stimulation capable of producing antibodies have been described for hosts: exposure to infecting oncospheres, subsequent development of immature cysts and then development of fertile cysts (LIGHTOWLERS; GOTTSTEIN, 1995; HOLCMAN; HEATH, 1997). Once the metacestodes have become established with their laminar layer, the antigens found in the germinal membrane, hydatid liquid and protoscolices remain sequestered within the hydatid cyst, thus ending the stimulation of the host. In humans, this usually means that there will be a negative serological response. Macromolecules leaving through microfissures of the laminar layer of mature metacestodes form a second source of stimulation for hosts, which will usually mean a positive serological response (LIGHTOWLERS; GOTTSTEIN, 1995).

In the light of the results of this study, it remains necessary to ascertain the time required for serological negativization, once the laminar layer has formed, in order to properly interpret the results from serological tests on sheep and humans.

\section{References}

Conder GA, Andersen FL, Schantz P. Immunodiagnostic tests for hydatidosis in sheep: an evaluation of double diffusion, immunoelectrophoresis, indirect hemagglutination, and intradermal 
tests. J Parasitol 1980; 66(4): 577-584. PMid:6775069. http://dx.doi. org/10.2307/3280512

Eckert J, Deplazes P, Craig P, Gemmel M, Gottstein B, Heath D, et al. Echinococcosis in animals: clinical aspects, diagnosis and treatment. In: Eckert J, Gemmel M, Meslin F, Pawlowski Z. WHO/OIE manual on Echinococcosis in Humans and Animals: a public health problem of global concern. WHO/OIE; 2001. p. 72-99.

Gatti A, Alvarez R, Araya D, Mancini S, Herrero E, Santillan G, et al. Ovine Echinococcosis: I. Immunological Diagnosis by Enzyme Immunoassay. Vet Parasitol 2007; 143(2): 112-121. Pmid:16979823. http://dx.doi.org/10.1016/j.vetpar.2006.08.022

Holcman B, Heath DD. The early stages of Echinococcus granulosus development. Acta Trop 1997; 64(1-2): 5-17. http://dx.doi.org/10.1016/ S0001-706X(96)00636-5
Larrieu E, Alvarez AR, Gatti A, Mancini S, Bigatti R, Araya D, et al. Fisiopatología y respuesta inmune de ovinos experimentalmente infectados con Echinococcus granulosus. Medicina (B. Aires.) 2009; 69(3): 341-346.

Larrieu E, Zanini F. Critical analysis of cystic echinococcosis control programs and praziquantel use in South America, 1974-2010. Rev Panam Salud Pública 2012; 31(1): 81-87. http://dx.doi.org/10.1590/ S1020-49892012000100012

Lightowlers M, Gottstein B. Echinococcosis/Hydatidosis: antigens, immunological and molecular diagnosis. In: Thompson R, Lymbery JM. The biology of Echinococcus granulosus and hydatid disease. London: George Allen and Unwin; 1995. p. 355-396.

Thompson RCA, McManus D. Aetiology: parasites and life cycles. In: Eckert J, Gemmel M, Meslin F, Pawlowski Z. WHO/OIE manual on Echinococcosis in Humans and Animals: a public health problem of global concern. WHO/OIE. France; 2001. p. 1-19. 